\title{
Effects of the Novel High-affinity 5-HT(1B/1D)-receptor Ligand Frovatriptan on the Rat Carotid Artery
}

\author{
Kremena E. Saracheva ${ }^{1,2}$, Natalia A. Prissadova ${ }^{3}$, Valentin I. Turiiski ${ }^{3}$, Valeri I. Slavchev ${ }^{3}$, \\ Atanas D. Krastev ${ }^{3}$, Damianka P. Getova ${ }^{4}$ \\ ${ }^{1}$ Department of Pharmacology and Clinical Pharmacology, Faculty of Medicine, Medical University of Plovdiv, Plovdiv, Bulgaria \\ ${ }^{2}$ Department of Pharmacology and Medical Toxicology, Faculty of Pharmacy, Medical University of Plovdiv, Plovdiv, Bulgaria \\ ${ }^{3}$ Department of Medical Physics and Biophysics, Faculty of Pharmacy, Medical University of Plovdiv, Plovdiv, Bulgaria \\ ${ }^{4}$ Laboratory of Neuropharmacology, Technological Center for Emergency Medicine (TCEMED), Plovdiv, Bulgaria
}

\section{Correspondence: \\ Kremena E. Saracheva, Depart- ment of Pharmacology and Clinical Pharmacology, Faculty of Medicine, Department of Pharmacology and Medical Toxicology, Faculty of Pharmacy, Medical University of Plovdiv, 15A Vassil Aprilov Blvd., 4002 Plovdiv, Bulgaria \\ E-mail:kremena_saracheva@ yahoo.com \\ Tel: +359 899778329}

Received: 21 Aug 2016

Accepted: 18 Sep 2016

Published Online: 29 Nov 2017

Published: 27 March 2017

Key words: serotonin, migraine, triptans, frovatriptan, carotid artery

Citation: Saracheva KE, Prissadova NA, Turiiski VI, Slavchev VI, Krastev AD, Getova DP. Effects of the novel high-affinity 5-HT(1B/1D)-receptor ligand frovatriptan on the rat carotid artery.

Folia Medica 2017;59(1):31-36. doi: 10.1515/folmed-2017-0006
Background: In blood vessels 5-HT stimulates sympathetic nerves, the endothelium and vascular smooth muscle cells. Triptans are specific anti-migraine drugs and they activate the serotoninergic $5 \mathrm{HT} 1 \mathrm{~b} / \mathrm{d}$ receptors causing vasoconstriction of the cerebral vessels.

Aim: To evaluate the effect of frovatriptan on isolated rat carotid artery.

Methods: Contractile activity of the preparations was registered isometrically. Krebs solution ( $\mathrm{pH}=7.4$ ) was used for washing smooth muscle $(\mathrm{SM})$ preparations aerated with $95 \% \mathrm{O}_{2}$ and $5 \% \mathrm{CO}_{2}$ at $37^{\circ} \mathrm{C}$. The 60 -minute adaptation of tone level of preparations was taken as a starting tone and the changes such as contraction or relaxation were calculated using it.

Results: Frovatriptan $\left(1 \times 10^{-6} \mathrm{~mol} / \mathrm{l}-1 \times 10^{-5} \mathrm{~mol} / \mathrm{l}\right)$ induced a contraction, but at higher concentrations it caused relaxation of the carotid artery. The L-norepinephrine contractile reaction was enhanced in the presence of frovatriptan. In the presence of 5-HT2 receptor antagonist, methysergide, frovatriptan increased the relaxation. In the presence of the specific a-1 receptor antagonist, prazosin, the frovatriptan-induced relaxation decreased.

Conclusion: The observed contractile effect of frovatriptan is probably associated with the main effect of the drug - activation of the serotoninergic $5 \mathrm{HT}_{1 \mathrm{~B} / 1 \mathrm{D}}$ receptors causing vasoconstriction of the cerebral vessels and their anti-migraine effect. At higher concentrations, frovatriptan, most likely via some non-specific mechanism, could activate the following intracellular chain reaction: stimulation of $a_{1 D}$ could activate eNOS which may increase in the concentration of NO which results in the final effect of relaxation.

\section{BACKGROUND}

Serotonin (5-hydroxytryptamine, 5-HT) exerts its multiplicity of physiological effects through an unsurpassed diversity of receptors. Some of these effects are mediated through actions of 5-HT in the central nervous system, whereas 5-HT also has multiple and diverse effects through direct interaction with 5-HT receptors in different parts of the cardiovascular system. ${ }^{1}$ In blood vessels 5 -HT stimulates sympathetic nerves, the endothelium and vascular smooth muscle cells. ${ }^{2}$

Triptans are specific anti-migraine drugs gener- ally recommended to patients whose conditions are refractory to analgesics. The therapeutic effect of triptans appears to be induced by activating the serotoninergic $5-\mathrm{HT}_{1 \mathrm{~B} / 1 \mathrm{D}}$ receptors in the trigeminovascular system causing vasoconstriction of the cerebral vessels and neuronal inhibition. Despite their relative selectivity, the vasoconstrictive activity of triptans also affects peripheral arteries, although to a lesser extent. ${ }^{3}$

Triptans differ markedly in terms of their pharmacokinetic and pharmacodynamic properties. Some triptans, such as sumatriptan, are considered to be 
fast-acting while also possessing greater risk of adverse events. Frovatriptan is one of the newest triptans and its distinct pharmacokinetic and pharmacodynamics profile reveals a clinical potential due to the long duration of action (half-life is 26h) and low incidence of side effects and drug interactions. The elimination half-life of frovatriptan is five times greater than that of other triptans, while the time to maximum concentration is similar to that of other triptans when given orally. ${ }^{4}$ It has high affinity to $5-\mathrm{HT}_{1 \mathrm{~B} / 1 \mathrm{D}}$ receptors and moderate affinity to $5-\mathrm{HT}_{7}$ receptors. It does not inhibit or induce cytochrome $\mathrm{P} 450$, associate to a low rate binding to plasma proteins, which in turn leads to a lower risk of drug interactions. ${ }^{5}$

\section{AIM}

To evaluate the effect of frovatriptan on isolated rat carotid artery.

\section{MATERIALS AND METHODS}

Male Wistar rats with initial body weight in the range of 220 to $280 \mathrm{~g}$ were provided by the Animal House of Medical University Plovdiv, Bulgaria. The rats were housed in standard laboratory conditions $\left(23-25^{\circ} \mathrm{C}, 50-55 \%\right.$ humidity and $12 / 12 \mathrm{~h}$ light/dark cycle) and fed with standard commercial food and given water ad libitum. At the beginning of the experiments the animals were euthanized by overdose anesthesia (ketamine and xylazine). Smooth muscle preparations of a carotis communis $0.8-1.0$ $\mathrm{mm}$ wide and $15 \mathrm{~mm}$ long were cut. All experiments were carried out according to the guidelines of using laboratory animals in EU- guidelines/EEC Directive of 1986.

Contractile activity of the preparations was registered isometrically using Tenzo detectors (Swema, Sweden). The initial mechanical stress of the preparations reached by the stretch tensosystem is a value corresponding to the tensile force of 10 $\mathrm{mN}$. Krebs solution $(\mathrm{pH}=7.4)$ used for washing the SM preparations was continuously aerated with a gas mixture of $95 \% \mathrm{O}_{2}$ and $5 \% \mathrm{CO}_{2}$ at $37^{\circ} \mathrm{C}$. A 60-minute adaptation of tone level of preparations was taken as a starting tone and changes such as contraction or relaxation were compared to it. During the adaptation the Krebs solution changed several times. The drug-caused reactivity of the SM preparations was measured and registered by gain stage Microtechna (the Czech Republic) and recorded using paper recorder (Linseis, Germany).

\section{Chemicals AND SOLutions}

The following chemicals were used: acetylcholine (Dispersa Baeschlin, Germany); DMSO (Sigma), frovatriptan succinate monohydrate (Sigma), methysergide maleate salt (Sigma), L-norepinephrine hydrochloride (Sigma), prazosin hydrochloride (Sigma).

The Krebs solution had the following composition (mM): $\mathrm{NaCl} 120 ; \mathrm{KCl} 5.9 ; \mathrm{CaCl}_{2} 2.5 ; \mathrm{MgCl}_{2}$ 1.2; $\mathrm{NaH}_{2} \mathrm{PO}_{4} 1.2 ; \mathrm{NaHCO}_{3} 15.4$ and glucose 11.5 (Merck).

\section{Statistics}

The data obtained were expressed as mean \pm standard error of the mean (SEM). The number of tissue preparations used in each experiment is indicated by $n$. Statistical differences were tested using the Student's t-test, and $\mathrm{P}<0.05$ was considered significant. All statistical analyses were performed using a specialized software SPSS, version 17.0 (SPSS Inc. Chicago, IL).

\section{RESULTS}

EFFECTS OF FROVATRIPTAN ON THE CONTRACTILE ACTIVITY OF SM PREPARATION OF CAROTID ARTERY.

At the concentration of $1 \times 10^{-6} \mathrm{~mol} / 1$ and $1 \times 10^{-5}$ $\mathrm{mol} / \mathrm{l}$, frovatriptan induced contraction in the SM preparations of carotid artery (Fig. 1).

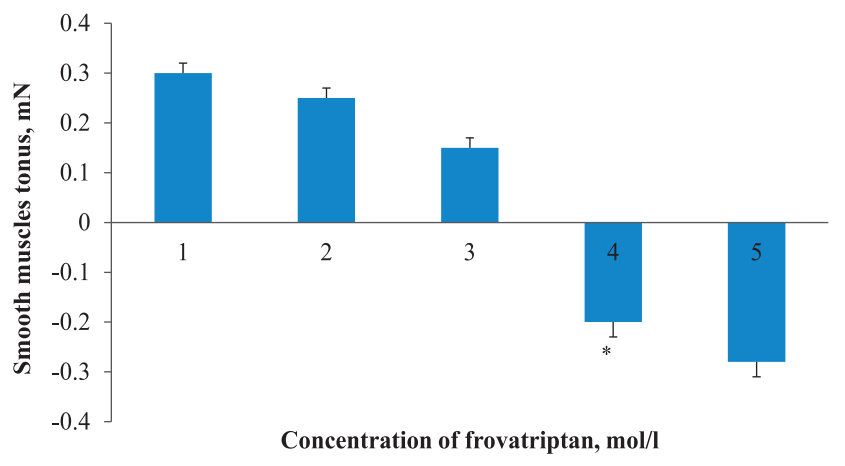

Figure 1. Changes in the contractile activity of isolated SM preparations of carotid artery after application of frovatriptan at concentration of $1 \times 10^{-6} \mathrm{~mol} / 1$ (1), $5 \times 10^{-6} \mathrm{~mol} / 1(2), 1 \times 10^{-5} \mathrm{~mol} / 1(3)$, and $5 \times 10^{-5} \mathrm{~mol} / 1$ (4) and $1 \times 10^{-4} \mathrm{~mol} / \mathrm{l}(\mathbf{5}),(\mathrm{n}=9)$.

At concentrations of $5 \times 10^{-5} \mathrm{~mol} / 1$ and higher frovatriptan provoked significant relaxation (Fig. 2). 


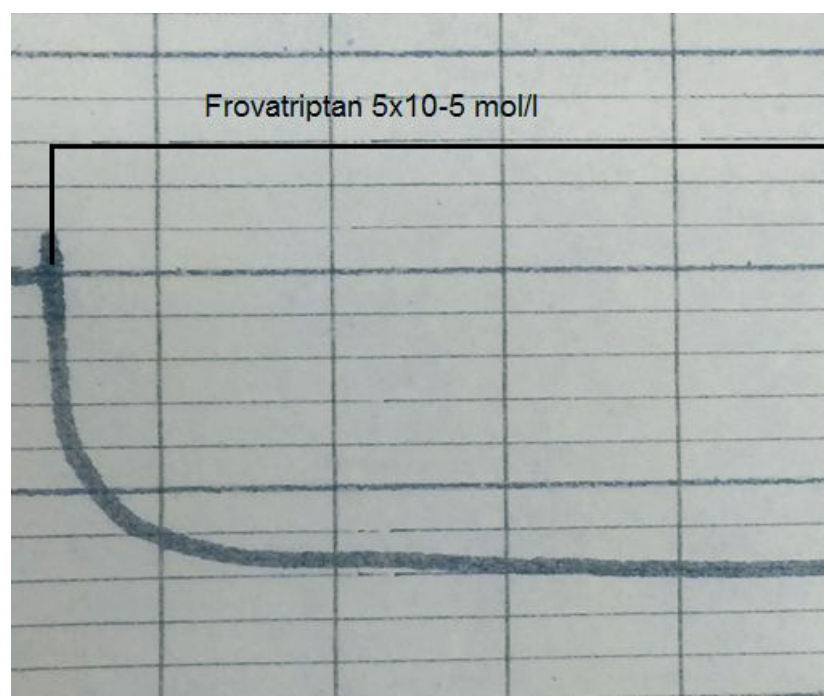

Figure 2. Frovatriptan isometric record of smooth muscle activation changes from isolated preparations of carotid artery $(\mathrm{n}=6)$.

EFFECTS OF $1 \times 10^{-5}$ MOL/L L-NOREPINEPHRINE ON THE CONTRACTILE ACTIVITY OF SM PREPARATIONS OF CAROTID ARTERY IN PRESENCE OF FROVATRIPTAN.

In the presence of frovatriptan at a concentration of $5 \times 10^{-5} \mathrm{~mol} / \mathrm{l}$ we observed a significant increase of the contractile reaction of L-norepinephrine $\left(1 \times 10^{-5}\right.$ mol/l) compared to the control reaction (Fig. 3).

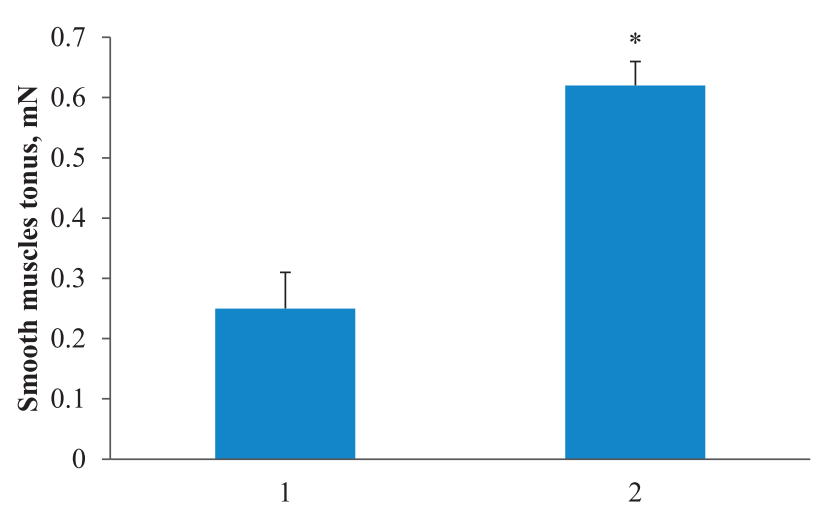

Figure 3. Changes in the tone of isolated SM preparations induced by L-norepinephrine $\left(1 \times 10^{-5} \mathrm{~mol} / \mathrm{l}(\mathbf{1})\right)$ and L-norepinephrine (2) in the presence of frovatriptan $\left(5 \times 10^{-5} \mathrm{~mol} / \mathrm{l}\right)(\mathrm{n}=7)$. Statistically significant effects are indicated by $*(\mathrm{P}<0.05)$.

EFFECTS OF $5 \times 10^{-5} \mathrm{MOL} / \mathrm{L}$ OF FROVATRIPTAN ON THE CONTRACTILE ACTIVITY OF SM PREPARATIONS OF CAROTID ARTERY IN PRESENCE OF METHYSERGIDE.

Frovatriptan $\left(5 \times 10^{-5} \mathrm{~mol} / \mathrm{l}\right)$ in the presence of the $5-\mathrm{HT}_{2}$ receptor antagonist methysergide $\left(1 \times 10^{-5}\right.$ $\mathrm{mol} / \mathrm{l})$ significantly increased the relaxation com- pared to the control reaction exerted by frovatriptan alone (Fig. 4).

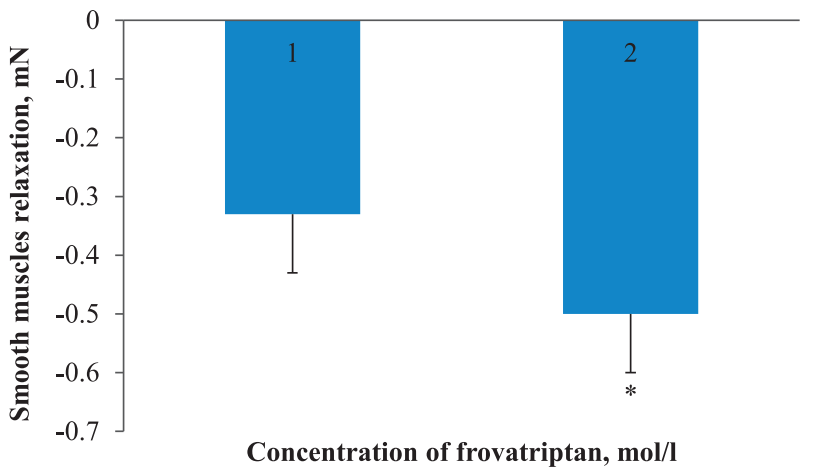

Figure 4. Changes in the tone of SM preparations of frovatriptan $\left(5 \times 10^{-5} \mathrm{~mol} / \mathrm{l}\right)(1)$ and of frovatriptan combined with methysergide $\left(1 \times 10^{-5} \mathrm{~mol} / \mathrm{l}\right)(2)(\mathrm{n}=7)$. Statistically significant effects are indicated by $*(\mathrm{P}<0.05)$.

EFFECTS OF $5 \times 10^{-5}$ MOL/L FROVATRIPTAN ON THE CONTRACTILE ACTIVITY OF SM PREPARATIONS OF CAROTID ARTERY IN PRESENCE OF PRAZOSIN.

In the presence of the specific alpha-1 receptor antagonist, prazosin $\left(1 \times 10^{-6} \mathrm{~mol} / \mathrm{l}\right)$, the relaxation induced by frovatriptan $\left(5 \times 10^{-5} \mathrm{~mol} / \mathrm{l}\right)$ significantly decreased compared to that in the controls by frovatriptan alone (Fig. 5).

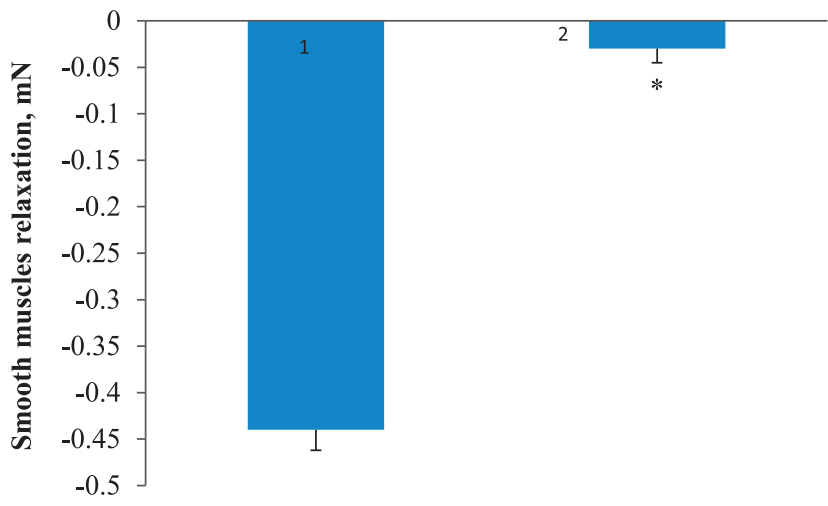

Figure 5. Changes in the tone of isolated SM preparation, induced by (1) frovatriptan $\left(5 \times 10^{-5} \mathrm{~mol} / \mathrm{l}\right)$ and (2) frovatriptan in the presence of prazosin $\left(1 \times 10^{-6} \mathrm{~mol} / \mathrm{l}\right)$ $(\mathrm{n}=7)$. Statistically significant effects are indicated by * $(\mathrm{P}<0.05)$.

\section{DISCUSSION}

Studies using isolated blood vessels provide a robust quantitative pharmacological comparison of drugs and may identify subtle differences between triptans. These differences are of scientific interest since, in theory, all triptans belong to the same 
class (i.e. $5-\mathrm{HT}_{1 \mathrm{~B} / 1 \mathrm{D}}$ receptor agonists) and therefore would be expected to have similar pharmacological actions. It is important to remember that any differences detected using in vitro studies should not be extrapolated and used as predictors or comparators of drug effects when administered to man.

5-HT was recognized as a substance isolated from blood serum (sero-) that could modify the tone of smooth muscles (-tonin). ${ }^{6-8}$

Frovatriptan, which belongs to the group of triptans, may act by constricting cranial vessels through $5-\mathrm{HT}_{1 \mathrm{~B}}$ receptors, by inhibiting peripheral trigeminal nerve afferents that innervate the vessels and pain-producing dura mater through 5-HT $1 \mathrm{D}$ receptors, or by inhibiting central trigeminal neuronal traffic through $5-\mathrm{HT}_{1 \mathrm{D}}$ receptors, or by a combination of these mechanisms. ${ }^{9}$

Our results shows that at concentrations of $1 \times 10^{-6} \mathrm{~mol} / 1$ and $1 \times 10^{-5} \mathrm{~mol} / 1$ frovatriptan induces contractions in SM preparations of carotid artery. This effect is probably related to the drug's main action - activation of serotoninergic $5-\mathrm{HT}_{1 \mathrm{~B} / 1 \mathrm{D}}$ receptors causing vasoconstriction of the cerebral vessels and their anti-migraine effect. It is well known that a-adrenoceptors play an important role in the regulation of vascular tone and blood pressure and that stimulation of the receptors mediate constriction of the isolated carotid artery. ${ }^{10}$

There are $3 \alpha-1$ adrenergic receptor subtypes: $\alpha 1 \mathrm{~A}, \alpha 1 \mathrm{~B}$, and $\alpha 1 \mathrm{D}$, all of which signal through the Gq/11 family of G-proteins and different subtypes show different patterns of activation. They activate mitogenic responses and regulate growth and proliferation of many cells. Catecholamines like norepinephrine (noradrenaline) and epinephrine (adrenaline) influence signaling pathways through the $\alpha_{1}$-adrenergic receptor in the central and peripheral nervous systems. $\alpha_{1 A^{-}}$and $\alpha_{1 B^{-A R s ~ l o c a l i z e d ~ t o ~}}$ the plasma membrane while $\alpha_{1 \mathrm{D}}$-ARs accumulate intracellularly. ${ }^{11}$

There is evidence in the literature that the activation of $\alpha_{1}$-adrenoceptors induces relaxation in rabbit bronchial artery ${ }^{12}$ and rat pulmonary arteries, in a process involving the endothelial production and release of nitric oxide (NO). In the rat carotid artery, phenylephrine produce an endothelium-dependent relaxation mediated by $\alpha_{1 \mathrm{D}}$ adrenoreceptors and involving the endothelial NO synthase (eNOS). ${ }^{13}$

Frovatriptan possesses higher $5-\mathrm{HT}_{1 \mathrm{~B}}$ agonist affinity and less affinity to $\alpha_{1 \mathrm{D}}$ adrenoreceptors. Our experiment showed that in its lower concentration frovatriptan occupied by priority $5-\mathrm{HT}_{1 \mathrm{~B}}$ receptors, and only then the NO activation pathway of $\alpha_{1 \mathrm{D}}$ receptors could be possible. After all this a smooth muscle contraction is observed in the $1 \times 10^{-6} \mathrm{~mol} / 1$ and $1 \times 10^{-5} \mathrm{~mol} / 1$ drug concentrations.

Despite the drug's lower $\alpha_{1}$-adrenoreceptor affinity in higher concentrations, it could be balanced under the following intracellular pathway: activation of $\alpha_{1 \mathrm{D}}$-ARs - NO synthesis - guanylate cyclase activation - increasing of internal cGMP - activation of protein kinase $\mathrm{G}$ (PKG). On the one hand PKG could influence directly the contractile machinery of smooth muscles ${ }^{14}$, on the other hand it could block L-type $\mathrm{Ca}^{2+}$ channels (in terms of $\mathrm{Ca}^{2+}$ influx reduction, necessary for muscle contraction) ${ }^{15}$ and on third hand PKG could activate calcium pumps whish also leads to reduction of intracellular calcium. The overall processes cumulation leads to $5-\mathrm{HT}_{1 \mathrm{~B}}$ and $\alpha_{1 \mathrm{D}}$ activation and subsequent smooth muscle relaxation at a concentration of $5 \times 10^{-5}$ mol/l of frovatriptan.

Such a hypothesis is supported by the results of experiments conducted with methysergide (specific inhibitor (5HT) receptor) and prazosin (specific inhibitor of alpha-1 receptors). Our data shows that the block 5-HT receptors by methysergide is probably due to activation of the $\alpha_{1 \mathrm{D}}$ receptors by frovatriptan.

The blockade of $\alpha_{1}$ receptors by prazosin reduced significantly the frovatriptan-induced relaxation which confirms the probable involvement of $\alpha_{1 D}$ receptors in the realization of its effects. As a result of experiments conducted in the presence of frovatriptan $\left(5 \times 10^{-5} \mathrm{~mol} / \mathrm{l}\right)$, the contractile response to L-norepinephrine was significantly increased compared to control reaction on the carotid artery. Our results also suggest that frovatriptan predominantly at higher concentrations probably by non-specific mechanism, which could activate the following intracellular chain reaction: stimulation on $\alpha_{1 \mathrm{D}} \rightarrow$ activation of eNOS $\rightarrow$ increase in the concentration of $\mathrm{NO}^{16}$ and subsequent relaxation, which is atypical for the triptans.

In conclusion, frovatriptan in concentrations of $1 \times 10^{-6} \mathrm{~mol} / 1,1 \times 10^{-5} \mathrm{~mol} / 1$ induces contractions in the carotid artery which is due to the activation of 5-HT $1 \mathrm{~B} / \mathrm{D}$ receptors. At higher concentrations $\left(5 \times 10^{-5} \mathrm{~mol} / \mathrm{l}\right)$ frovatriptan induces relaxation atypical for triptans. This effect could be a result from the activation of $\alpha_{1 D}$ receptors. On the other hand, at a concentration of $5 \times 10^{-5} \mathrm{~mol} / \mathrm{l}$ frovatriptan potentiates the effect of L-norepinephrine which in turn 
can activate the following intracellular cascade: stimulation of $\alpha_{1 \mathrm{D}}$ receptors followed by activation of eNOS and subsequently increased concentration of NO with the final effect of relaxation.

Apparently frovatriptan initiates very complicated and balanced pathways via $5-\mathrm{HT}_{1 \mathrm{~B}}$ and $\alpha_{1 \mathrm{D}}$ receptors, which, depending on its concentration, could lead to contraction or relaxation of the carotid artery.

\section{ACKNOWLEDGEMENTS}

This study is part of the Scientific Project SDP 14/2015 of MU-Plovdiv.

\section{REFERENCES}

1. Kaumann JA, Levy FO. 5-hydroxytryptamine receptors in the human cardiovascular system. Pharmacol Ther 2006;111(3):674-706.

2. Geerts IS, Matthys KE, Herman AG, et al. Involvement of 5-HT ${ }_{1 \mathrm{~B}}$ receptors in collar-induced hypersensitivity to 5-hydroxytryptamine of the rabbit carotid artery. Br J Pharmacol 1999;127(6):1327-36.

3. Roberto G, Piccinni C, D'Alessandro R, et al. Triptans and serious adverse vascular events: Data mining of the FDA Adverse Event Reporting System database. Cephalalgia 2014;34(1):5-13.

4. Tullo V, Valguarnera F, Barbanti P, et al. Comparison of frovatriptan plus dexketoprofen $(25 \mathrm{mg}$ or 37.5 $\mathrm{mg}$ ) with frovatriptan alone in the treatment of migraine attacks with or without aura: A randomized study. Cephalalgia 2014;34(6):434-45.

5. Savi L, Mogavero S, Egan CG. Efficacy and pharmacokinetic activity of frovatriptan compared to rizatriptan in patients with moderate-to-severe migraine. Drug Des Devel Ther 2014;8:983-92.

6. Rapport MM, Green AA, Page IH. Serum vasoconstrictor, serotonin; isolation and characterization. J Biol Chem 1948;176(3):1243-51.

7. Erspamer V, Asero B. Identification of enteramine, the specific hormone of the enterochromaffin cell system, as 5-hydroxytryptamine. Nature 1952;169 (4306):800-1.

8. Page IH, McCubbin JW. Modification of vascular response to serotonin by drugs. Am J Physiol 1953;174(3):436-44.

9. Goadsby PJ. Serotonin 5-HT $1 \mathrm{~B} / 1 \mathrm{D}$ receptor agonists in migraine comparative pharmacology and its therapeutic implications. CNS Drugs 1998;10(4):271-86.

10. Willems EW, Heiligers JPC, De Vries P, et al. Alpha1adrenoceptor subtypes mediating vasoconstriction in the carotid circulation of anaesthetized pigs: possible avenues for antimigraine drug development. Cephalalgia 2001;21:110-9.

11. McCune DF, Edelmann SE, Olges JR, et al. Regulation of the cellular localization and signaling properties of the alpha(1B)- and alpha(1D)-adrenoceptors by agonists and inverse agonists. Mol Pharmacol 2000;57(4):659-66.

12.Zschauer AO, Sielczak MW, Smith DA, et al. Norepinephrine-induced contraction of isolated rabbit bronchial artery: role of alpha 1- and alpha 2-adrenoceptor activation. J Appl Physiol 1997;82(6):1918-25.

13. de Andrade CR, Fukada SY, Olivon VC, et al. Alpha1 $\mathrm{D}$-adrenoceptor-induced relaxation on rat carotid artery is impaired during the endothelial dysfunction evoked in the early stages of hyperhomocysteinemia. Eur J Pharmacol 2006;543(1-3):83-91.

14.Lee MR, Li L, Kitazawa T. Cyclic GMP causes $\mathrm{Ca}^{2+}$ desensitization in vascular smooth muscle by activating the myosin light chain phosphatase. J Biol Chem 1997;272(8):5063-8.

15.Carvajal JA, Germain AM, Huidobro-Toro JP, et al. Molecular mechanism of cGMP-mediated smooth muscle relaxation. J Cell Physiol 2000;184(3):409-20.

16. Lowry JL, Brovkovych V, Zhang Y, et al. Endothelial nitric-oxide synthase activation generates an inducible nitric-oxide synthase-like output of nitric oxide in inflamed endothelium. J Biol Chem 2013;288(6):4174-93. 


\title{
Эффект воздействия нового высокоэффективного 5-HT(1B/1D)- рецептора лиганда фроватрипана на сонную артерию крысы
}

\author{
Кремена Е. Сарачева ${ }^{1,2}$, Наталия А. Присадова ${ }^{3}$ Валентин И. Турийски , Валери И. \\ Славчев ${ }^{3}$, Атанас Д. Крастев ${ }^{3}$, Дамянка П. Гетова ${ }^{4}$ \\ ${ }^{1}$ Кафедра фармакологии и клинической фармакологии, Факультет медицины, Медицинский университет, Пловдив, \\ Болгария \\ 2 Кафедра фармакологии и медицинской токсикологии, Факультет фармации, Медицинский университет, Пловдив, \\ Болгария \\ 3 Кафедра медицинской физики и биофизики, Факультет фармации, Медицинский университет-Пловдив. Болгария \\ 4 Лаборатория нейрофармакологии, Технологический центр неотложной медицины, Пловдив, Болгария
}

Адрес для корреспонденции: Кремена Е. Сарачева, Кафедра фармакологии и клинической фармакологии, Факультет медицины, Медицинский университет - Пловдив, Кафедра фармакологии и медицинской токсикологии, Факультет фармации, Медицинский университет - Пловдив, бул. Васил Априлов 15A, 4002

Пловдив, Болгария

E-mail: kremena_saracheva@ yahoo.com

тел: +359 899778329

Дата получения: 21 августа 2016

Дата приемки: 18 сентября 2016

Дата онлайн публикации: 29 ноября 2016

Дата публикации: 27 марта 2017

Ключевые слова: серотонин, мигрень, триптаны, фроваптрипан, сонная артерия

Образец цитирования: Saracheva KE, Prissadova NA, Turiiski VI, Slavchev VI, Krastev AD, Getova DP. Effects of the novel high-affinity $5-\mathrm{HT}(1 \mathrm{~B} / 1 \mathrm{D})$-receptor ligand frovatriptan on the rat carotid artery.

Folia Medica 2017;59(1):31-36. doi: 10.1515/folmed-2017-0006
Введение: В кровеносных сосудах 5-НТ стимулирует симпатические нервы, эндотелий и клетки гладких мышц сосудов. Триптаны являются специфическими антимигренозными медикаментами, которые активируют серотонинэргические $5 \mathrm{HT}_{1 \mathrm{~B} / 1 \mathrm{D}}$ рецепторы, вызывая вазоконстрикции сосудов головного мозга.

Цель: Оценить эффект воздействия фроватрипана на изолированную сонную артерию крысы.

Методы: Сократительная активность препаратов зарегистрирована в изометрическом режиме. Раствор Кребса ( $\mathrm{pH}=7.4)$ использован для отмывания препаратов гладких мышц (ГМ), аэрированных 95\% О2 и 5\% СО2 при $37^{\circ} \mathrm{C}$. 60-минутная адаптация уровня цвета препаратов взята в качестве контрольного цвета и изменения в виде сокращения и релаксации измерены в соответствии с ним.

Результаты: Фроватрипан ( $1 \times 10^{-6}$ мол/л - $1 \times 10^{-5}$ мол/л) индуцирует сокращение, но в более высоких концентрациях вызывает релаксацию сонной артерии. L-норэпинефриновая сократительная реакция была усилена наличием фроватрипана. При наличии 5-НT2 рецептора антагониста, метисергида, фроватрипан усиливает проявление релаксации.При наличии специфического a-1 рецептора антагониста, празосина, фроватрипан-индуцированная релаксация понижается.

Заключение: Установленный сократительный эффект фроватрипана вероятно связан с основным эффектом препарата - активацией серотонинэргических $5 \mathrm{HT}_{1 \mathrm{~B} / 1 \mathrm{D}}$ рецепторов, вызывающих вазоконстрикции сосудов головного мозга и их антимигренозный эффект. В более высоких концентрациях фроватрипан, вероятнее всего неизвестным неспецифическим механизмом может активировать следующий интрацеллюлярный каскад реакций: стимуляция a1D может активировать еАОС (эндотелиальную синтазу оксида азота), которая может повыситься в концентрации AO, что приводит к конечному эффекту релаксации. 